\title{
New finds from the Anglo-Saxon monastery at Hartlepool, Cleveland
}

\author{
R.J. CRAMP \& R. DANIELS*
}

The Northumbrian monastic communities, and their crafts, are fundamental to the study of 7th-century Britain. New excavation has revealed significant evidence for the community at Hartlepool, as well as moulds and crucibles from fine metal-working on the site.

In the early $640 \mathrm{~s} A D$ the abbess Hieu established a monastery at Heruteu, but shortly afterwards moved on. Hilda was appointed abbess in her place and set about the organization of the monastery under the guidance of Aidan (Bede: Bk IV, Ch. XXIII (XXI), 407, 409). Following the battle of Winwaed in 655 AD, King Oswy of Northumbria dedicated his daughter Aelffled to God and gave her into the care of Hilda at Heruteu. In 657 Hilda founded the monastery at Streaneshalch (Whitby) and, taking her charge with her, established the house there (Bede: Bk III, Ch. XXIV, 293). As far as is known, Hilda retained control of the monastery at Heruteu, but the transference of royal patronage to Streaneshalch probably ensured that the monastery of Heruteu never developed to the same extent as Whitby. The monastery at Heruteu then disappears from the record, but was supposed destroyed by the Vikings in the 9th century.

In the 19th and early 20 th centuries, building work at Hartlepool uncovered a number of inhumations oriented $\mathrm{N}-\mathrm{S}$, some of which were accompanied by small rectangular name-stones (Cramp 1984: 97-101, pls. 84, 85). These support the tradition that Hartlepool was the site of the monastery of Heruteu. In 1968 excavation at Lumley Street, $\mathrm{N}$ of the parish church on Hartlepool Headland, located timber buildings of Anglo-Saxon date, further reinforcing the suggestion that the monastic complex was in the vicinity of the present 12 th-century church (Cramp 1976: 222).
Excavations undertaken by Cleveland County Archaeology Section during 1984 and 1985 uncovered a complex of timber buildings and an associated boundary. The excavation produced the first Hartlepool-style name-stone to be found this century, as well as a series of fine metal-working moulds. It seems likely that this is part of the monastic complex known to St Hilda. As such the Church Close excavation represents the most extensive investigation of the earliest phase of a Northumbrian monastery so far undertaken.

\section{The excavation}

Between June 1984 and October 1985 Cleveland County Archaeology Section excavated a site immediately to the $\mathrm{N}$ of St Hilda's Church, Hartlepool Headland. The site, at Church Close (NZ5233), covered an area of c. $1500 \mathrm{sq} . \mathrm{m}$ and ran $E$ from the frontage of Durham Street (FIGURE 1). The excavation recovered evidence for various medieval properties and, more significantly in the present context, a sequence of buildings of Anglo-Saxon date.

Evidence for 16 timber buildings was recovered, which, added to the seven or eight buildings known from the Lumley Street excavation, confirms the existence of a substantial settlement complex. The buildings have all been laid out on a common E-W alignment, but differ in that seven have their long axis oriented $\mathrm{E}-\mathrm{W}$, the remaining nine being $\mathrm{N}-\mathrm{S}$. Two constructional techniques have been employed: individual post-settings, and trenches into

\footnotetext{
* R.J. Cramp, Department of Archaeology, University of Durham, 46 Saddler Street, Durham. R. Danicls, Cleveland County Archaeology Section, PO Box 41, Ormesby Road, Middlesbrough, Cleveland T's 3 OYZ.
} 


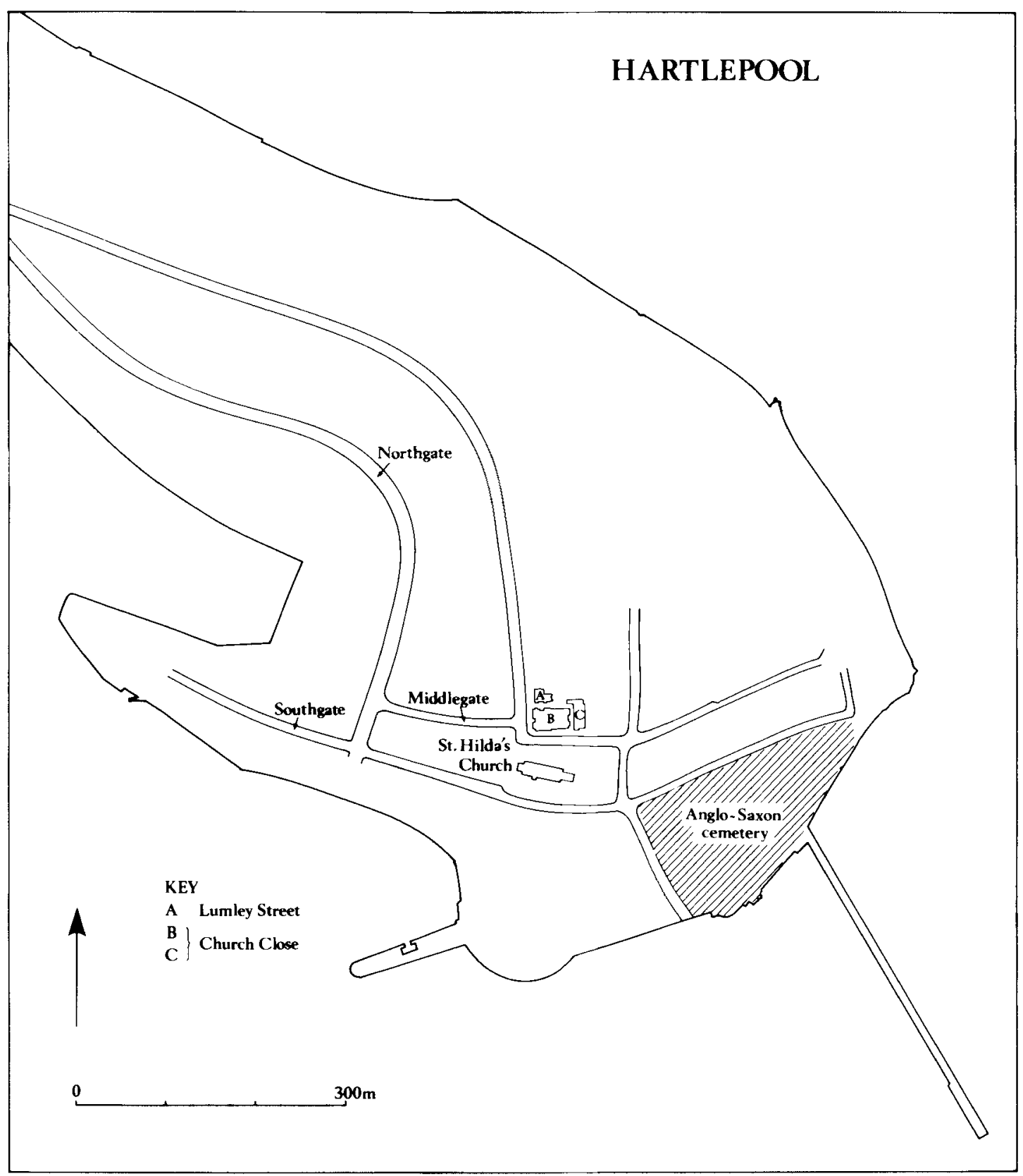

FIGURE 1. Map showing the location of the Lumley Street excavation (A) and the Church Close excavations (B, C) in relation to St Hilda's Church and the site of the Saxon cemetery on Hartlepool Headland. 


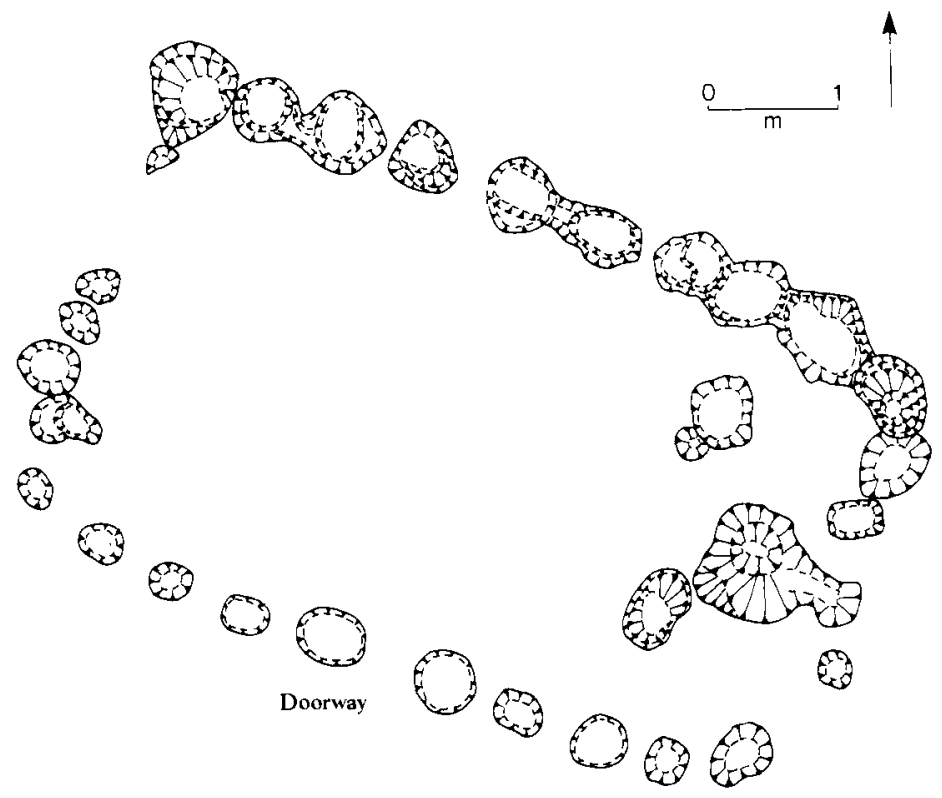

FIGURE 2. Buildings VIII/X.

which the posts were set. Where observed, the stratigraphic relationship suggests that the latter was a later development, although two buildings, XVII and IX, used a combination of both techniques.

Ten complete building plans were recovered. They fall into three plan types. The first plan type comprises simple rectangular buildings, of which there are seven, ranging in size from 3.74 $\times 4.3 \mathrm{~m}$ to $4.2 \times 6.5 \mathrm{~m}$. Four of these buildings have N-S long axis, with a doorway in the centre of the E wall (e.g. buildings VIII and X, FIGURE 2). The remaining three are oriented $\mathrm{E}-\mathrm{W}$, with two having doorways in the E wall. There is no doorway discernible in the third.

The second plan type consists of buildings with internal partitions. Two complete plans of this type of building were recovered, and a third survived in part. Building XVII (FIGURE 3), oriented $\mathrm{N}-\mathrm{S}$, was $5.7 \times 3.8 \mathrm{~m}$. The partition, sited at the southern end, created two rooms, the larger measuring $2.84 \times 3.0 \mathrm{~m}$ internally, and the smaller $1.7 \times 3.0 \mathrm{~m}$. There was no obvious doorway from this building, and both end-walls were very slight. The second partitioned building, XIV (FIGURE 4), oriented $\mathrm{E}-\mathrm{W}$, measured $6.4 \times 4.2 \mathrm{~m}$; a partition at the eastern end created a small room, $0.84 \times 3.2 \mathrm{~m}$. The entrance to this building was in the centre of the southern wall.

The third plan type is represented by a single building, IX (FIGURE 5). This, the longest building located, was oriented E-W. It comprises two distinct units, the larger and easternmost measuring $5.9 \times 2.6 \mathrm{~m}$ externally, and the western measuring $2.5 \times 3.2 \mathrm{~m}$. The

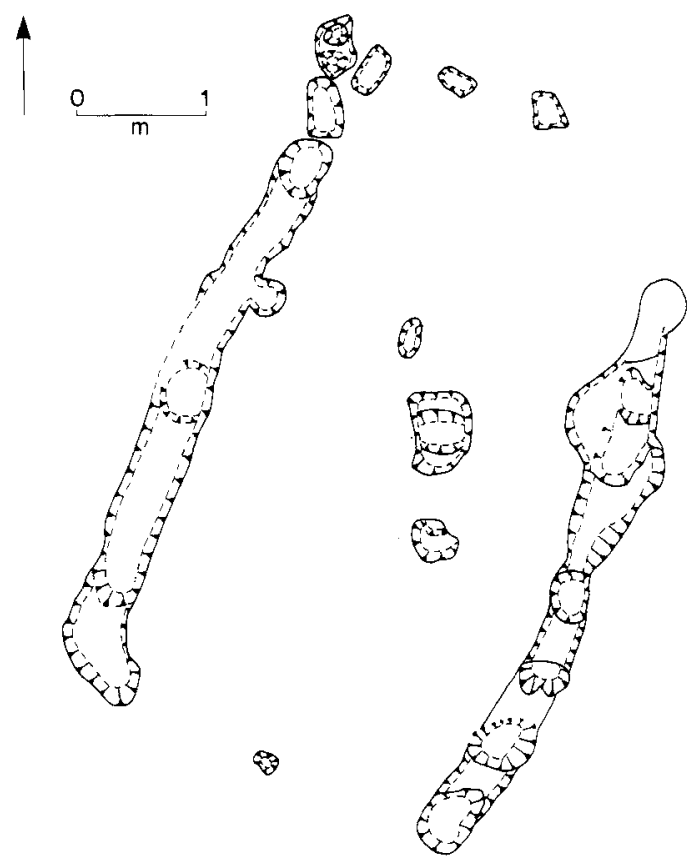

FIGURE 3. Building XVII. 


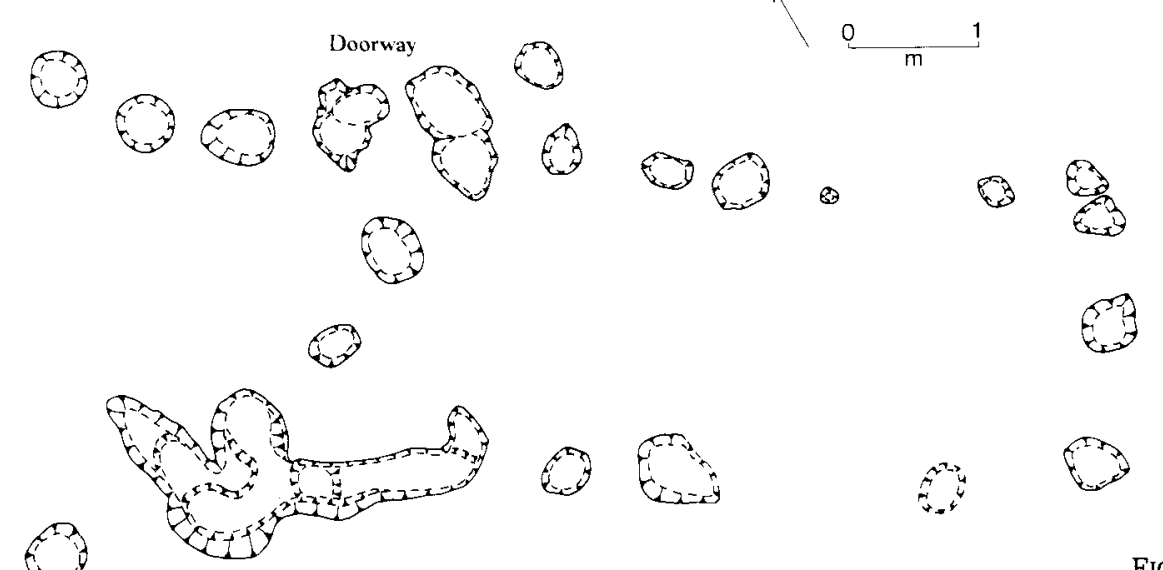

FIGURE 4. Building XIV.

double post-settings in the $\mathrm{N}$ wall, adjacent to the partitions, may well indicate a doorway in this position.

There is little evidence for the activities carried out in these buildings, most of the occupation debris being lost to later agricultural activity on the site. The absence of any indication of hearths may be significant, and the evidence of metal-working debris from the site suggests some crafts were being carried out in the area. In the absence of any other evidence these buildings can be compared with those at Whitby (Cramp 1976: 229), and may be interpreted as serving a variety of functions as part of an organized community.
These buildings fall into the early medieval building tradition postulated by James, Marshall \& Millett (1984), in that all are built of substantial earthfast timbers and use both posthole and wall trench techniques of construction. The buildings appear to be precisely laid out. There is evidence for the pairing of timbers across buildings. Gabled roofs can be inferred. Of the three partitioned buildings, two of the partitions were sited at the eastern end. The buildings differ from the majority of those noted by James, Marshall \& Millett in having only a single doorway, but this is sited in one of the long walls of each building, generally the eastern one. The presence of only a single

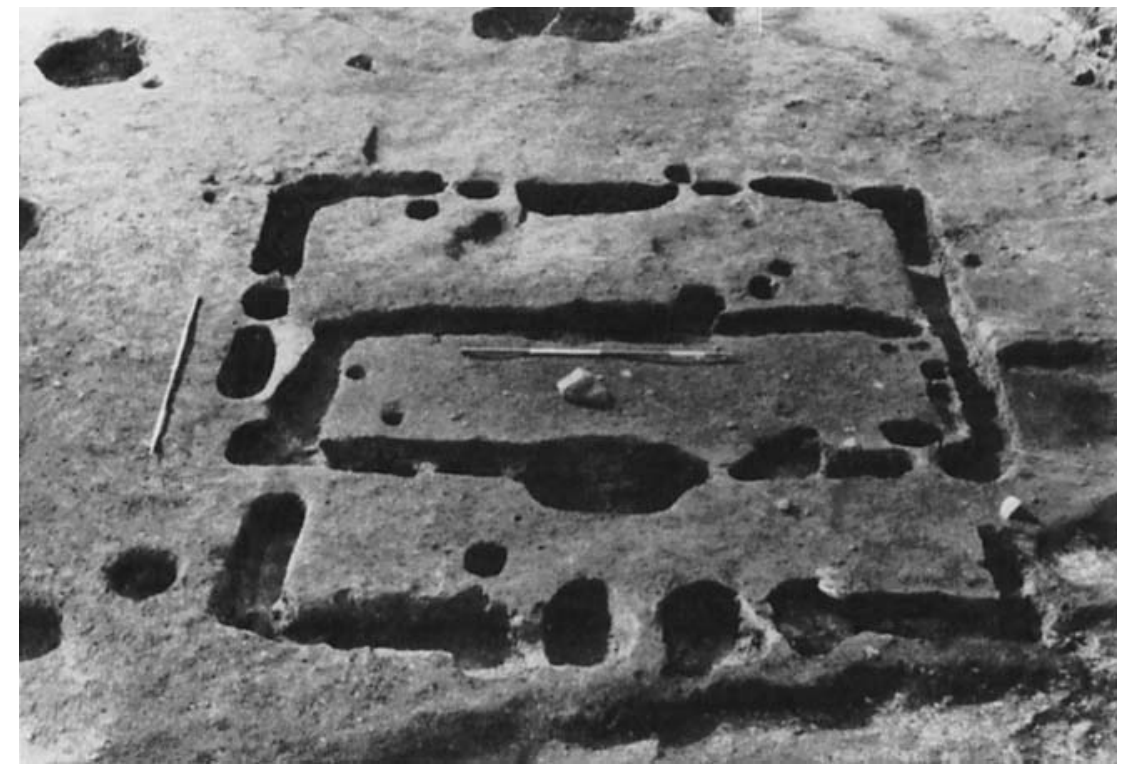

FIGURE 5. Building IX. 
doorway is probably a result of the small size of the buildings, but otherwise these structures are set firmly within the constructional tradition of the period. This suggests that there was no inherent distinction between buildings constructed for secular use and those used for ecclesiastical purposes in the earliest period of Anglo-Saxon monasticism. The distinction lies, rather, in the high proportion of small buildings within a planned complex and their density of distribution compared with that on a secular site.

A boundary complex of three components was also recovered; the earliest, a series of deep post-pits, was superseded by a palisade trench laid out on the same alignment. The trench fill contained bronze-working debris and the moulds discussed below. To the exterior and parallel with these features were a further two large post-pits set $12.5 \mathrm{~m}$ apart. Their function is uncertain, but a parallel might be drawn with the Irish tradition of placing crosses outside the monastic enclosure (Herity 1983: 270-3). A similar feature at Cheddar was interpreted as housing a flagpole (Rahtz 1979: 166-7). The post-pits and palisade trench suggest a monastic enclosure, but as the buildings also occur outside this boundary their relationship to it must await the clarification of radiocarbon dating. Here again there is an obvious parallel with Whitby, where features contemporary with the monastery occur beyond the putative'vallum monasterii'.

The earthfast timber buildings were demolished and had been overlain by traces of a series of stone sills which represent the bases of composite or wooden structures, the foundations not being substantial enough to suggest stone buildings. The plans of three buildings of this type were recovered; one lay $\mathrm{N}-\mathrm{S}$ and measured $7.5 \mathrm{~m} \times 3.5 \mathrm{~m}$. A hearth was sited at the NE corner of this building, and a sill-stone in the $\mathrm{E}$ wall indicated a doorway set $2 \mathrm{~m}$ in from the SE corner. The other two buildings were smaller, measuring $3 \times 4.2 \mathrm{~m}$ and $2 \times 2.5 \mathrm{~m}$. There was insufficient evidence to suggest any further detail, although an opening $1.8 \mathrm{~m}$ wide in the $S$ wall of the former suggested a doorway. One of these buildings contained occupation debris, including a coin of Eadberht issued between 737 and 758. Both buildings were oriented E-W.

\section{Stonework}

There have been few finds of stonework from the Church Close site, a paucity which is in notable contrast with the richness of the Whitby collection (Peers \& Radford 1943). The explanation for this probably lies in the early date of the Hartlepool site and its subsequent secondary relationship to Whitby. A number of the finds are, however, of particular significance. Stone fragments of two possible window arches suggest the presence of at least one stone building in the vicinity, presumably one of the focal structures of the monastery. The namestone (FIGURE 6), unfortunately from a secondary context, measures $0.20 \times 0.23 \mathrm{~m} \times 83$ $\mathrm{mm}$ thick. It has an incised border set $12 \mathrm{~mm}$ in from the edge. The central cross is of the F1 type (Cramp 1984: xvi) with semi-circular terminals and a round centre. Each corner contains an arc, and two small crosses have been incised on either side of the upper half of the stone. The lower half has a name inscribed on it, of which three letters, $b b a$, are clearly legible. This may well be the name Abba or Ebba, a common female name of the period. This stone, oth-

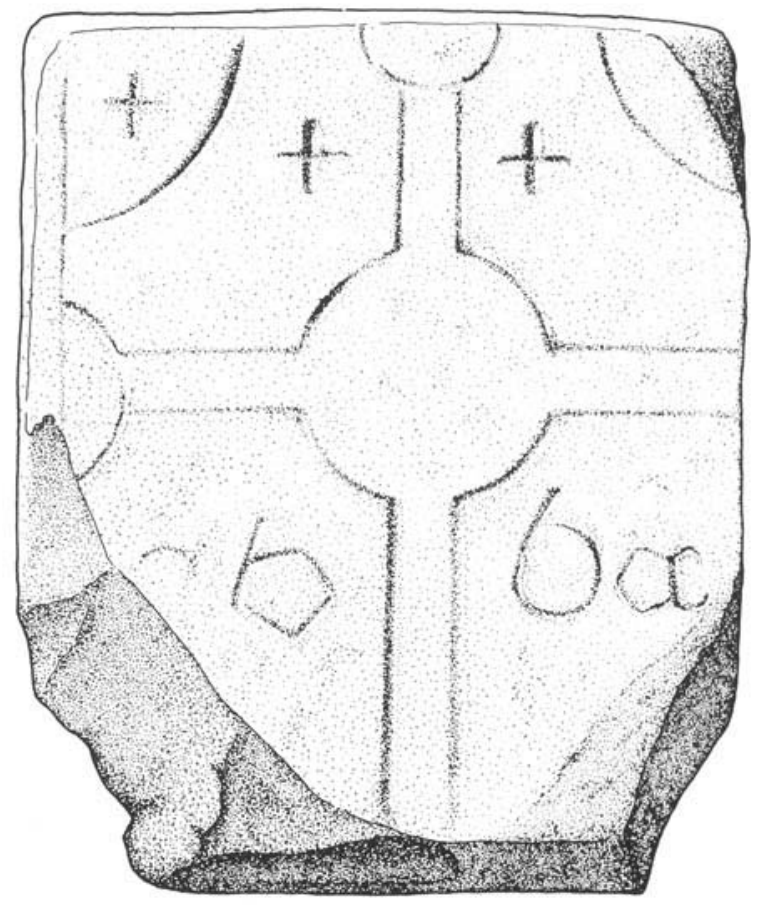

FIGURE 6. Nume-stone recovered from a secondary context at Church Close, Hartlepool. 
erwise quite typical of the Hartlepool series, is the only one with arcs in the corners. Both the letters and the two crosses in the upper half of the stone have the appearance of later additions and confirm the suggestion of large-scale manufacture of these stones for later use (Cramp 1984: 101).

\section{Metalworking moulds}

The deposit of mould and crucible fragments from the backfill of the palisade trench confirm the importance of Hartlepool within its period. They provide the best evidence so far excavated of the metal-working traditions of Anglo-Saxon Northumbria. Whitby, Jarrow and Barrow-onHumber have provided some evidence of metalworking, but these finely-decorated moulds are unique for an Anglo-Saxon monastic site, and in the quality of their detail are outstanding.

The Hartlepool crucibles are of two main types: a small hemispherical type, with two feet, width $25 \mathrm{~mm}$, height $30 \mathrm{~mm}$ (one of which has traces of copper-alloy residues), and a wider type with a flatter base. Unfortunately the three joining fragments of this only make up a fragment of the whole. The surviving height is 36 $\mathrm{mm}$, the width $7 \mathrm{~mm}$. Other fragments B.91 (97) have, on cursory examination, visible droplets of silver. This is confirmed by X-ray fluorescence (Justine Bayley, pers. comm.). Further scientific examination of the crucible fragments could confirm how many metals were being worked on the site and may enable comparisons to be made with other sites such as the Mote of Mark, Barrow-on-Humber, and Jarrow. More intensive examination of all the crucible fragments might provide evidence for the type of lidded crucible with handle which is common alike in the Celtic west and Germanic north in the 1st millennium AD (Lamm 1980: 98-103). As Leslie Alcock (1963: 48) pointed out some time ago, there is considerable variety in the forms of crucibles in the Early Christian period, and these may have been diffused by itinerant smiths.

The clay moulds for constructing fine metal are an important find. Parts of two-piece moulds, they are made from a very fine medium-hard clay which fires to a variety of colours between dark grey and brownish red, although most of the pieces are grey. Several of the pieces have 'fixing marks' consisting of a cut or finger depression. And as well as the decorated clay moulds described below, there are many fragments of the runnel-mouths of moulds or the plain pieces of the round twopiece valves. In addition, in the earlier excavations of 1968, a stone mould for casting metal bars was discovered, of length $160 \mathrm{~mm}$, width $90 \mathrm{~mm}$, height $62 \mathrm{~mm}$. It was formed from a limestone boulder and, like similar moulds from Birsay (Curle 1982: 46, illus. 28) or from Dunadd (Justine Bayley, pers. comm.), was used for multiple casting of bars of different lengths. One impression is of length $55 \mathrm{~mm}$, depth 13 $\mathrm{mm}$, width $15-17 \mathrm{~mm}$; a larger one, incomplete, had maximum dimensions of length $94 \mathrm{~mm}$, depth $19 \mathrm{~mm}$, greatest width $10 \mathrm{~mm}$. At both Dunadd and 'the Pictish horizon' of Birsay such moulds, which seem to have been used for casting metals into standard units, were associated with decorated clay moulds. The Hartlepool debris is not as extensive as is found on such sites as Lagore, the Mote of Mark or Helgo, nor was it found in situ.

\section{The decorated clay moulds}

Three moulds survive with complex decoration:

\section{Free-armed cross (FIGURE 7A)}

Part of a circular mould engraved with a freearmed cross, measuring $20 \times 12 \mathrm{~mm} \times 7 \mathrm{~mm}$ thick.

This mould has a saucer-shaped rim. The cross is a type with wide curving ends to the arm - a variant of type E10 (Cramp 1984: fig. 2). There is not enough left of the interlace pattern on either arm to be certain of its type, save that the patterns are different on each arm, and that on the 'upright' arm ends in a pattern E knot, whilst the surviving horizontal arm contains a complete and turned pattern $\mathrm{F}$. The centre of the head appears to have contained some form of circular motif.

Crosses with splayed and rounded ends to the arms were discovered in the monastic site of Whitby, either as plain appliqués or combined into elaborate double motifs and with each arm containing different interlace patterns (Peers \& Radford 1943: fig. 10.6, pls. XXI, XXII(11)]. Several of the free-standing stone crosses from Whitby also have arms with rounded ends. This mould may have been used for casting either a mount or a personal cross. 


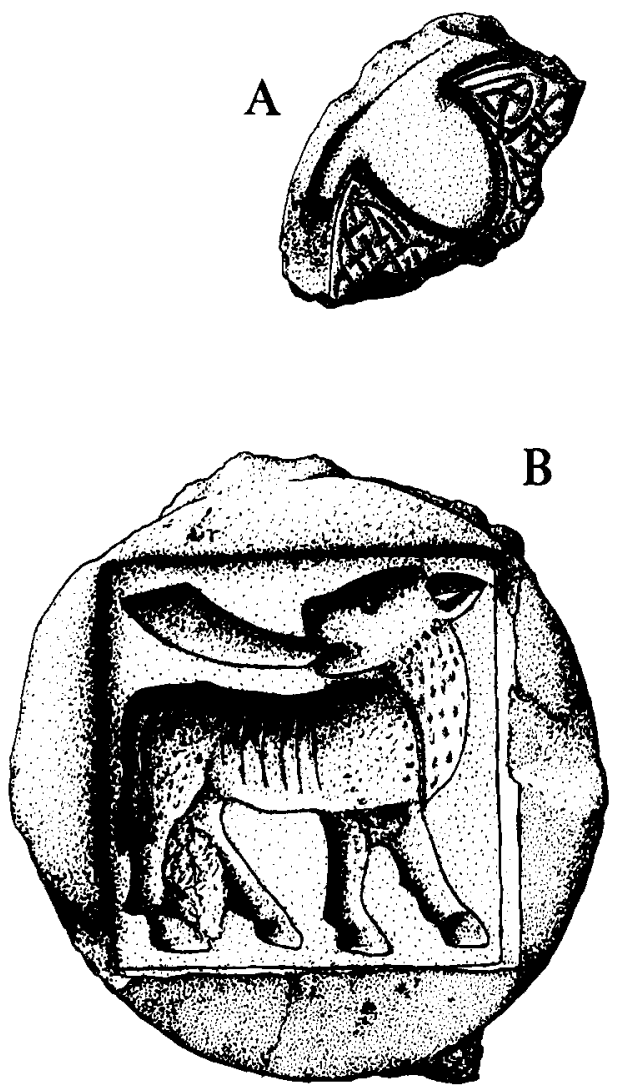

2 The Apocalyptic animal (FIGURE 7B)

The basic mould is round, broken at the edges, but constructed in the same smooth greyish clay as some of the plain dish-shaped pieces. Its external dimensions are $30 \times 35 \mathrm{~mm} \times 8 \mathrm{~mm}$ deep; the impression is $20 \times 20 \mathrm{~mm} \times 2 \mathrm{~mm}$ deep.

The impression is almost square. Both the outline and the figure of the animal are delicately engraved. The creature is shown walking to the spectator's right, its head is turned back, and it holds a trumpet in its mouth. It has a naturalistic head with a round eye and large sharply-cut triangular ear. It has hooved feet and a long tail. Its coat is marked on the neck and haunches with fine slashes. Across the body there are deep concentric incisions which might have been used to convey the ribs of the creature or the long hairs of its coat.

The stance of the creature with back-turned head, and indeed the form of its head, at first sight reminds one of the Lamb of God, as it appears for example on the Ravennate sarco-

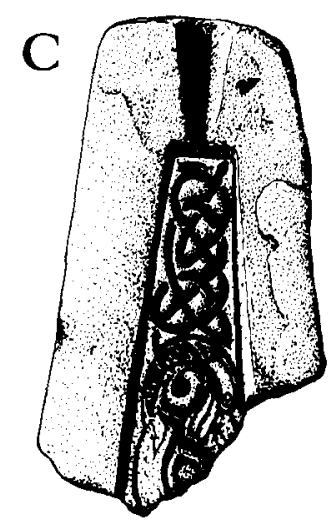

FIGURE 7.

A. Mould 1, fragment of free-armed cross.

B. Mould 2, the Apocalyptic animal.

C. Mould 3, the ribbon animal mould.

phagi of the 5th and 6th centuries. But the peculiarity of the trumpet accessory - which would be proper for one of the four Apocalyptic creatures but is not an attribute of the Lamb makes one wonder whether this, too, is such a symbol. The Lamb as symbol of Christ, whether in His guise as sacrificial victim, or Judge as in Revelation Chapter 4, can stand against a cross, or on the hill from which streams flow, or can appear to be opening the sealed book. From the time this image first appears in Christian art c. 400 , the Lamb is usually haloed (Schiller 1971:). The haloed Lamb appears for example on the early 8th-century crosses of Ruthwell and Bewcastle (Collingwood 1927: 113, 118). It is true that there are also 'unaccompanied' depictions such as that at St Radegunde's reading-desk of the 6th century (Schiller 1971: pl. 592), or the centre of the lost Hoddom cross (Collingwood 1927: fig. 51).

Lambs can also represent the saved or even the apostles in early Christian art. In neither case are they customarily haloed but they do 
appear in groups. A single Lamb blowing a trumpet seems to be unparalleled.

The symbols of the evangelists can be depicted with or without haloes and are depicted blowing trumpets. This Hartlepool figure can then more convincingly be seen as the vitulus (calf), symbol of St Luke. Comparable 'naked' figures, without wings, haloes or books, can be found from the 6th century, as at San Vitale, Ravenna (Bruce-Mitford 1960: pl. 25a), and occur in this form on such Insular manuscripts as The Book of Durrow, or the Echternach or Trier Gospels (Bruce-Mitford 1960: pl. 26 \& 160-1). In this 'Celtic' type the calf is not horned, nor is the calf horned amongst the winged evangelist symbols which surround the enthroned Christ in the Codex Amiatinus (Bruce-Mitford 1960: pl. 24). On the other hand, the imago vitulus which is associated with St Luke in the Lindisfarne Gospels, and which appears, with the other symbols, on St Cuthbert's Coffin, is horned and has all the 'attributes' of haloes, wings and book. Nevertheless, two of the Lindisfarne Gospels symbols the angel of St Matthew, and the lion of St Mark - are depicted with plain curving trumpets in their mouths exactly like that on the Hartlepool mould.

In discussing this rare attribute of the trumpet, and comparing it with much later depictions such as on the 10th-century Copenhagen Gospels (fols. 17v \& 82v), or the Benedictional of St Aethelwold (fol 19v), Bruce-Mitford (1960: 142-57, pls. 22-3) concluded that there must have been a full set of evangelist symbols with trumpets available for the Lindisfarne Gospel artist (Eadfrith) to copy from, but he chose to adapt several features in both his evangelist portraits and symbols. The calf with trumpet here supports Bruce-Mitford's contention that a full set of trumpeting figures was available in Northumbria, and provides evidence of a similar individuality for the anonymous Hartlepool artist. He chose the youthful calf figure of the 'Celtic' world, but equipped it with an apocalyptic trumpet. Its back-bent head, which is most unusual in an evangelist symbol, may reflect the stance of the Lamb, but was necessary anyway to form a compact image. One may suppose that this Hartlepool piece was one of a set of four mounts such as the Brandon plaque from Suffolk (Wilson 1984: illus. 123), which could have surrounded either a figure of
Christ in majesty, as on the Cuthbert Coffin, or possibly a Lamb, as on the Hart Cross (Cramp 1984: 95, pl. 82, 416-18). Altogether, it is an important addition to the body of Northumbrian art history and iconography.

\section{The ribbon animal mould (FIGURE 7C)}

The mould's external surviving dimensions are $28 \times 15 \times 8 \mathrm{~mm}$ deep; the impression is $5 \times 3$ $\mathrm{mm}$, with a depth of $1 \mathrm{~mm}$. It is part of a two-piece mould, with runnel, and what may be a placing groove on one side. The clay is fine, greyish and smooth.

The mould is a tapering rectangle, as is the frame for the incised pattern. This shows on the left a fine geometric interlace beginning with a complete pattern F knot (Cramp 1984: fig. 16) which derives from the body of a ribbon animal. The organization of its body is unclear, although there seems to be a coil under its neck. Its beaked jaws are closed, its eye is backpointed, and its head is plain whilst its body is hatched. In type it is clearly part of the Insular tradition; see the Lindisfarne Gospels (fol. 69r), or the creatures on the Durham Cathedral MS (AII. 17.) (Webster 1982: fig. 2a-c). Hatching of this kind may be seen in Insular metalwork, for example of a panel on the back of the Hunterston brooch (Stevenson 1974: pl. XI A).

The fine-line interlace relates this piece to the manuscript tradition, and again places Hartlepool within the Insular context. This mould is rather more worn than the others. It could perhaps have been used for casting ornamental panels for jewellery or a piece of church plate.

All of these decorated pieces are important because they diversify the artistic repertoire of 7th- and 8th-century Northumbria, so long confined to the major centres of Lindisfarne, Whitby and Wearmouth/Jarrow. The Insular taste of this metalwork is clear but it is not provincial work, and the high quality of the design and cutting are indicative of the resources the Hartlepool community could draw upon at this period.

Acknowledgements. Anchor Housing Association is to be thanked for permission to excavate on Church Close; the project was supported by the Manpower Services Commission and Historic Buildings and Monuments Commission. Our thanks go to Mr B.E. Vyner for his advice and help throughout the excavation, and to Dr M. Millett for his comments on the buildings. 


\section{References}

ALCOCK, L. 1963. Dinas Powys, an iron age, dark age and medieval site in Glamorgan. Cardiff.

BRUCE-MITFORD, R.L.S. 1960. Decoration and Miniatures, part IV, in T.D. Kendrick et al. (ed.), Evangelionum Quattuor Codex Lindisfarnensis.

Colgrave, B. \& R.A.B. MyNORS (ed.). 1969. Bede's Ecclesiastical History of the English People. Oxford.

COLLINGWOOD, W.G. 1927. Northumbrian Crosses of the pre-Norman age. London.

CRAMP, R. 1976. Monastic sites, in D. Wilson (ed.), The archaeology of Anglo-Saxon England: 201-52. London: Methuen

1978a. The Anglian tradition in the 9th century, in J.T. Lang (ed.), Anglo-Saxon and Viking Age sculpture and its context: papers from the Collingwood symposium on insular sculpture from 800 to 1066: 1-32. Oxford: British Archaeological Reports. British Series 49.

$1978 \mathrm{~b}$. The evangelist symbols and parallels in Anglo-Saxon sculpture, in R.T. Farrell (ed.), Bede and Anglo-Saxon England: 118-30. Oxford: British Archaeological Reports. British Series 46. 1984. Corpus of Anglo-Saxon stone sculpture: Durham and Northumberland 1. London: British Academy.

CURLE, C.L. 1982. Pictish and Norse finds from the
Brough of Birsay 1934-74. Edinburgh: Society of Antiquaries of Scotland. Monograph 1.

HERITY, M. 1983. The buildings and layout of early Irish monasteries before the year 1000 , Monastic Studies 14: 247-84.

JAMES, S., A. MARShALl \& M. MILLETT. 1984. An early medieval building tradition, Archaeological Journal 141: 182-215.

KITZINGER, E. 1956. The Coffin-reliquary, in C.F. Battiscombe (ed.), The relics of St Cuthbert. Durham.

LAMM, K. 1980. Early medieval metalworking on Helgo in central Sweden, in W.A. Oddy (ed.), Aspects of early metallurgy: 97-116. London: British Museum. Occasional Paper 17.

PEers, C.R. \& Raleigh RAdFord, C.A. 1943. The Saxon monastery of Whitby, Archaeologia 89: 27-88.

RAHTZ, P. 1978. The Saxon and medieval palaces at Cheddar. Oxford: British Archaeological Reports. British Series 65.

SCHILLER, G. 1971. Ikonographie der Christlide Kunst 3. Gütersloh.

STEVENSON, R.B.K. 1974. The Hunterston brooch and its significance, Medieval Archaeology 18: 16-42.

WEBSTER, L. 1982. Stylistic aspects of the Franks Casket, in R.T. Farrell (ed.), The Vikings: 20-31. London: Phillimore.
Book Chronicle

continued from p. 423

Jean Prodhomme. La préparation de publications archéologiques. Paris: Editions de la Maison des Sciences de l'Homme, 1987. Documents d'Archéologie Francaise 8. 184 pages, copiously illustrated. $195 \mathrm{~F}$ paperback.

H.A.G. Brijder, A.A. Drukker \& C.W. Neeft (ed.). Enthousiasmos: essays on Greek and related pottery presented to J.M. Hemelrijk. Amsterdam: Allard Pierson Museum, 1986. Allard Pierson Series 6. $x+220$ pages, many $b / w$ illustrations. Hardback.

Emilie Riha. Römisches Toilettgerät und medizinische Instrumente aus Augst und Kaiseraugst. Augst: Römermuseum, 1986. Forschungen in Augst 6.188 pages, $74 \mathrm{~b} / \mathrm{w}$ illustrations. Hardback.

Alan Isaacs \& Jennifer Monk (ed.). The Cambridge illustrated dictionary of British heritage. Cambridge $\&$ New York: Cambridge University Press, 1986/7. viii + 484 pages, many illustrations. £14.95.
Mark Patton. Jersey in prehistory. Warminster: Aris \& Phillips, 1987. 176 pages, 18 plates, 39 figures. $£ 15$.

Churches of South-East Wiltshire. London: HMSO for the Royal Commission on the Historical Monuments of England, 1987. xix +259 pages, $573 \mathrm{~b} / \mathrm{w}$ illustrations, many diagrams and tables. $£ 19.95$.

Philip Mansel. The Eagle in splendour: Napoleon $I$ and his court. London: George Philip, 1987. 232 pages, many $b / w$ and 12 colour illustrations. £16.95.

Marlene Suano. Sabellian-Samnite Bronze Belts in the British Museum. London: British Museum, 1986. Occasional Paper no. 57. 77 pages, many figures and tables, 27 plates. Peter Ucko. Academic freedom and apartheid: the story of the World Archaeological Congress. London: Duckworth, \& New York: Plenum, 1987. xiii + 305 pages, $16 \mathrm{~b} / \mathrm{w}$ illustrations. £9.95 paperback. 